\title{
A statistical approach to represent small-scale variability of permafrost temperatures due to snow cover
}

\author{
K. Gisnås ${ }^{1}$, S. Westermann ${ }^{1,2}$, T. V. Schuler ${ }^{1}$, T. Litherland ${ }^{1}$, K. Isaksen ${ }^{3}$, J. Boike ${ }^{4}$, and B. Etzelmüller ${ }^{1}$ \\ ${ }^{1}$ Department of Geosciences, University of Oslo, Oslo, Norway \\ ${ }^{2}$ Center for Permafrost, Department of Geography and Geology, University of Copenhagen, Copenhagen, Denmark \\ ${ }^{3}$ Norwegian Meteorological Institute, Oslo, Norway \\ ${ }^{4}$ Alfred Wegener Institute, Potsdam, Germany \\ Correspondence to: Kjersti Gisnås (kjersti.gisnas@geo.uio.no)
}

Received: 6 January 2014 - Published in The Cryosphere Discuss.: 22 January 2014

Revised: 1 October 2014 - Accepted: 2 October 2014 - Published: 14 November 2014

\begin{abstract}
In permafrost environments exposed to strong winds, drifting snow can create a small-scale pattern of strongly variable snow heights, which has profound implications for the thermal regime of the ground. Arrays of 26 to more than 100 temperature loggers were installed to record the distribution of ground surface temperatures within three study areas across a climatic gradient from continuous to sporadic permafrost in Norway. A variability of the mean annual ground surface temperature of up to $6^{\circ} \mathrm{C}$ was documented within areas of $0.5 \mathrm{~km}^{2}$. The observed variation can, to a large degree, be explained by variation in snow height. Permafrost models, employing averages of snow height for grid cells of, e.g., $1 \mathrm{~km}^{2}$, are not capable of representing such sub-grid variability. We propose a statistical representation of the sub-grid variability of ground surface temperatures and demonstrate that a simple equilibrium permafrost model can reproduce the temperature distribution within a grid cell based on the distribution of snow heights.
\end{abstract}

\section{Introduction}

In permafrost areas, seasonal snow cover is a crucial factor for the ground thermal regime (e.g., Luetschg et al., 2004, 2008; Ishikawa, 2003; Goodrich, 1982; Zhang et al., 2001). The main influences of snow cover are low thermal conductivity, high surface albedo and a delay in active layer thawing during snowmelt in spring or summer (Harris et al., 2009). Snow heights above $0.6-0.8 \mathrm{~m}$ have been found to effectively insulate the ground from the atmosphere (e.g., Hae- berli, 1973), and the importance of the timing of the earlywinter snow has been emphasized in a number of studies (Zhang, 2005; Zhang et al., 2001; Luetschg et al., 2008; Gubler et al., 2011; Vonder Muhll et al., 1998). Snow redistribution caused by wind drift creates a pattern of different snow heights resulting in spatially variable ground temperatures (e.g., Isaksen et al., 2011; Farbrot et al., 2011). This effect is of great importance in mountain permafrost areas due to higher wind speeds, rough topography and open terrain. The strong redistribution of snow by wind results in accumulation of snow in deep hollows, while large open areas are bare-blown.

The heterogeneity of the ground surface temperatures (GSTs) must be systematically quantified as an important background for understanding mesoscale variability of nearsurface ground temperatures (Etzelmüller, 2013). In most applications in permafrost areas, grid-based numerical models calculating ground temperature or active layer thickness operate on spatial scales too coarse to resolve the variability of snow heights. For the Norwegian mainland, the ground thermal models "CryoGRID 1" and "CryoGRID 2" have been implemented at a $1 \mathrm{~km} \times 1 \mathrm{~km}$ spatial resolution at which they are capable of capturing the regional distribution of permafrost (Gisnås et al., 2013; Westermann et al., 2013). One of the principal uncertainties is the effect of sub-grid variation in snow cover (Langer et al., 2013), so that procedures for the downscaling of snow heights are required to get a satisfactory representation of the ground thermal regime.

In this study, we present a proof-of-concept approach for a statistical representation of ground temperatures in the 
Nordic area based on the distribution of snow heights within a grid cell, using the simple equilibrium permafrost model CryoGRID 1. The concept is validated for three study areas along a transect from continuous permafrost on Svalbard to sporadic permafrost in Southern Norway, where arrays of temperature loggers facilitate to estimate the true distribution of GSTs.

\section{Study areas}

In three areas in Norway, arrays of temperature loggers measuring the ground surface temperature have been established (Fig. 1): Ny-Ålesund, Svalbard ( $\left.78^{\circ} 55^{\prime} \mathrm{N}, 11^{\circ} 50^{\prime} \mathrm{E}\right)$ - a high-Arctic site in the continuous permafrost zone; Juvvasshøe, Jotunheimen $\left(61^{\circ} 41^{\prime} \mathrm{N}, 8^{\circ} 23^{\prime} \mathrm{E}\right)$ - a high mountain site in central southern Norway located in the continuous to discontinuous permafrost zone; Finse, Hardangervidda mountain plateau $\left(60^{\circ} 34^{\prime} \mathrm{N}, 7^{\circ} 32^{\prime} \mathrm{E}\right)$ - a low alpine site in southern Norway located in the sporadic permafrost zone. A summary of field locations and climatic settings is given in Table 1. Ny- $\AA$ lesund (10-50 m a.s.1.) is located on the Brøgger peninsula at the west coast of Spitsbergen, and has a maritime climate with cool summers and relatively mild winters. It is located within the continuous permafrost zone, with an annual mean air temperature during the hydrological years $2012-2013$ of $-3.8,2.5$ and $1.2^{\circ} \mathrm{C}$, higher than the long-term average in the periods 1961-1990 and 1981-2010. The annual precipitation was $464 \mathrm{~mm}$, according to the official meteorological station (eKlima, 2013). However, a substantial undercatch of measured solid precipitation must be assumed in these climatic conditions, so that the true precipitation is probably $50 \%$ higher than that measured (Førland and Hanssen-Bauer, 2000). The seasonal snow cover normally lasts from mid-September to well into June, with inter-annual variations in the length of the snow season from 215 to 315 days (Winther et al., 2002). The average snow height in the terrain is around $0.6 \mathrm{~m}$, with variations from 0 to $3 \mathrm{~m}$ due to wind drift (Bruland et al., 2001). The prevailing wind direction is southeasterly along the Kongsfjord, with generally gentle wind speeds. The average wind speed was $3.5 \mathrm{~m} \mathrm{~s}^{-1}$ during the winter of 2012-2013, with a maximum wind speed of $20.8 \mathrm{~m} \mathrm{~s}^{-1}$ (eKlima, 2013). The $\mathrm{Ny}-$ Ålesund field site is located $2 \mathrm{~km}$ southwest of Ny-Ålesund, half way between the fjord and the terminus of the nearest glacier Brøggerbreen, in gentle topography ranging from 10 to $50 \mathrm{~m}$ a.s.1. The study area is located around the Bayelva climate and soil monitoring station (red circle in Fig. 1, top) that has provided a record of climate and soil variables since 1998 (Westermann et al., 2009, 2011; Boike et al., 2003). The surface cover in the Bayelva area alters between mud boils and sparse vegetation consisting of low vascular plants, mosses and lichens. The soil texture is silty to clayish in a gravely matrix, and it is, in general, low in organic content (Boike et al., 2008). Active layer thicknesses ranging from 1.6 to $2.0 \mathrm{~m}$
(Westermann et al., 2010) and mean annual ground temperatures at the bottom of the active layer between -2 and $-3{ }^{\circ} \mathrm{C}$ are reported from the field area (Roth and Boike, 2001; Boike et al., 2003).

The Juvvasshøe field site (1374-1497 m a.s.1.) is located in the northeastern slope down from Juvvasshøe (1894 m a.s.1.) (Fig. 1, middle), a small hill northwest of Galdhøpiggen (highest peak in Norway, $2469 \mathrm{~m}$ ). The Galdhøpiggen massive is located at the divide between the more maritime climate on the west coast and the continental climate in eastern parts of Norway. The terrain is open, with very sparse vegetation and a ground cover dominated by moraine deposits. The field area is well investigated in terms of ground thermal regime and permafrost distribution. A few hundred meters southwest of Juvvasshøe, mean annual ground temperatures measured in a $10 \mathrm{~m}$ deep borehole at $1851 \mathrm{~m}$ a.s.l. for the two periods $1982-1986$ and $2008-2010$ were $-2.2^{\circ} \mathrm{C}$ (Ødegård et al., 1992) and $-1.6^{\circ} \mathrm{C}$ (Farbrot et al., 2011), respectively. At the top of Juvvasshøe, data from a $129 \mathrm{~m}$ deep borehole (Sollid et al., 2000) show a very low geothermal gradient and indicate permafrost extending below a depth of $300 \mathrm{~m}$ (Isaksen et al., 2001, 2007) and a close relation of permafrost, ground surface and air temperatures (Isaksen et al., 2003). An altitudinal transect of shallow boreholes (10 m deep) was established in 2008 (Farbrot et al., 2011; Hipp et al., 2012). The lower limit of permafrost in this area is located at about 1450-1500 m (Farbrot et al., 2011; Hauck et al., 2004; Isaksen et al., 2002) and, during the last decade, has undergone warming and possible degradation (Isaksen et al., 2011).

The field site is located $400 \mathrm{~m}$ down the northeastern slope from Juvvasshøe, at a $15^{\circ}$ steep slope facing northeast. The location is chosen to intersect the lower limit of permafrost (Hauck et al., 2004) and coincides with a 14 yr record of bottom temperature of snow (BTS) and continuous ground surface temperature measurements, maximum snow height measurements and direct current (DC) resistivity profiles over a $500 \mathrm{~m}$ long transect (Isaksen et al., 2011). For the measurement period, annual mean air temperature at the field site was $-2.8^{\circ} \mathrm{C}$, while annual precipitation estimated by seNorge.no (2013) was around $1200 \mathrm{~mm} \mathrm{yr}^{-1}$. Calculated average snow height (without accounting for snow drift) was 1.5-2.0 m (Mohr, 2008; Saloranta, 2012; seNorge.no, 2013; Tveito et al., 2000). However, the observed average snow height was less than $1.0 \mathrm{~m}$, which is most likely caused by substantial wind drift of snow. During the winter of 20122013 , the average wind speed at the meteorological station at Juvvasshøe was $6.5 \mathrm{~m} \mathrm{~s}^{-1}$, with a maximum wind speed of $31.6 \mathrm{~m} \mathrm{~s}^{-1}$. As a result, large parts of the area are bare-blown during the entire snow season, while some areas experience snow heights up to $6 \mathrm{~m}$. The deep snow areas are covered by snow for approximately three-quarters of the year.

The Finse field site (1293-1332 ma.s.1.) is located in the upper part of a valley at the northern margin of the mountain plateau Hardangervidda. The $1 \mathrm{~km} \times 1 \mathrm{~km}$ field area is located to the west of Vesle Hansbunut, $3.5 \mathrm{~km}$ southeast of the 

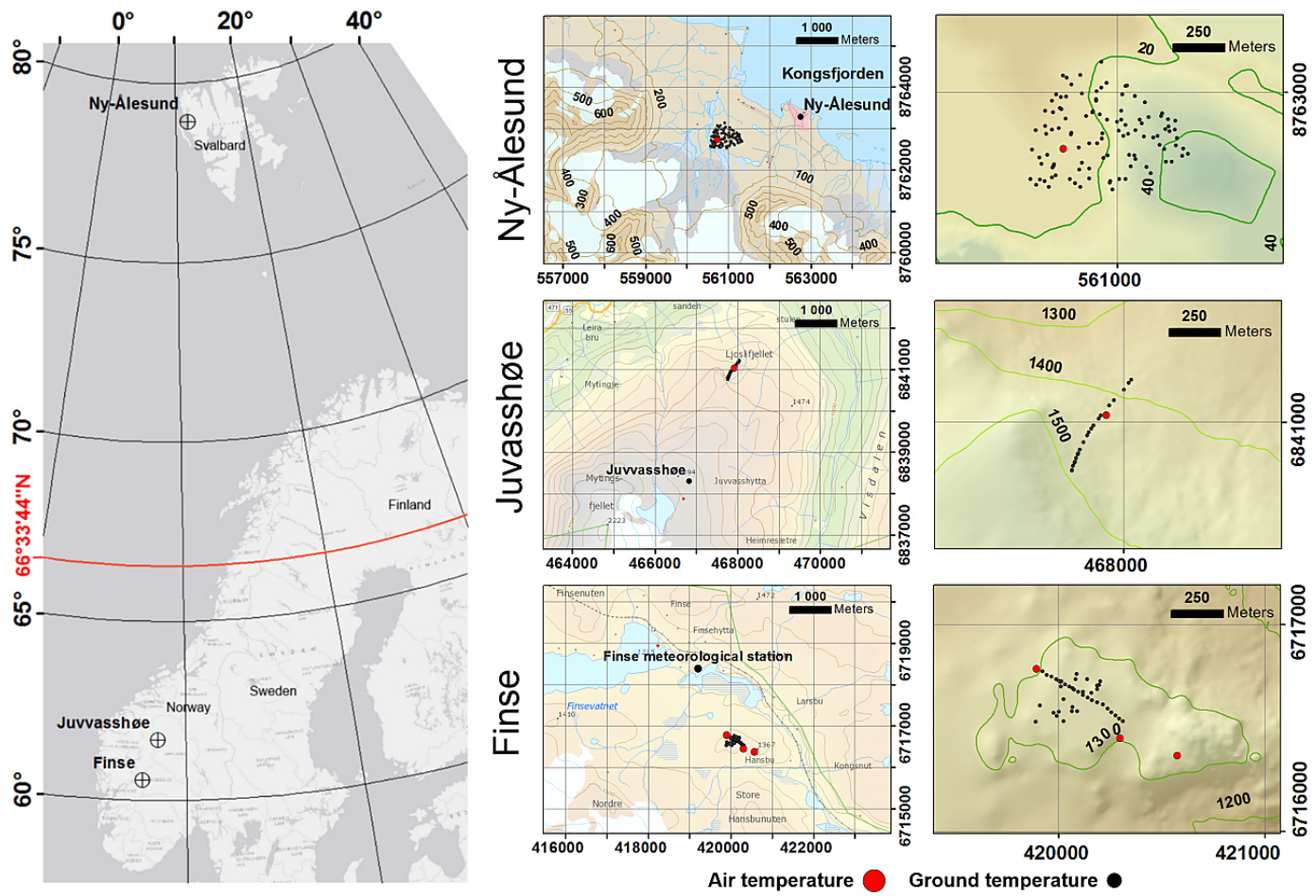

Figure 1. Study areas located along the gradient from continuous to sporadic permafrost in northern Europe: Ny-Ålesund, Svalbard; Juvvasshøe, Jotunheimen, southern Norway; Finse, Hardangervidda, southern Norway. Right column: distribution pattern of ground surface temperature (GST). Black dots: location of GST loggers. Red dots: air temperature at $2 \mathrm{~m}$ height.

Table 1. Site and climate characteristics for the measurement period 2012-2013. MAAT is the annual mean air temperature in the field area. MHS: average snow height in the terrain at snow maximum; MWWS: mean winter (Dec-Mar) wind speed; MaxWWS: maximum winter (Dec-Mar) wind speed. Wind speed at Juvvasshøe is measured at the meteorological station at the top of Juvvasshøe (1894 $\mathrm{m}$ a.s.1.).

\begin{tabular}{|c|c|c|c|}
\hline & Ny-Ålesund & Juvvasshøe & Finse \\
\hline Latitude & $78.6^{\circ} \mathrm{N}$ & $61.3^{\circ} \mathrm{N}$ & $60.2^{\circ} \mathrm{N}$ \\
\hline Altitude & $10-50 \mathrm{~m}$ a.s.1. & $1374-1497$ m a.s.l. & $1293-1332 \mathrm{~m}$ a.s.l. \\
\hline $\mathrm{MAAT}^{\circ} \mathrm{C}$ & $-3.8^{\circ} \mathrm{C}$ & $-2.8^{\circ} \mathrm{C}$ & $-2.2^{\circ} \mathrm{C}$ \\
\hline MHS & $0.6 \mathrm{~m}$ & $0.7 \mathrm{~m}$ & $1.6 \mathrm{~m}$ \\
\hline MWWS & $3.9 \mathrm{~m} \mathrm{~s}^{-1}$ & $6.5 \mathrm{~m} \mathrm{~s}^{-1}$ & $4.7 \mathrm{~m} \mathrm{~s}^{-1}$ \\
\hline Max WWS & $18.7 \mathrm{~m} \mathrm{~s}^{-1}$ & $31.6 \mathrm{~m} \mathrm{~s}^{-1}$ & $28.7 \mathrm{~m} \mathrm{~s}^{-1}$ \\
\hline No. GST loggers & 104 & 26 & 41 \\
\hline Measurement period & 9 Sep 2012-9 Sep 2013 & 27 Jul 2012-14 Jul 2013 & 25 Sep 2012-25 Sep 2013 \\
\hline Temporal resolution & $\begin{array}{l}\text { HOBO: } 4 \mathrm{~h} \\
\text { iButtons: } 4 \mathrm{~h}\end{array}$ & $\begin{array}{l}\text { UTL-3: } 2 \mathrm{~h} \\
\text { iButtons: } 4 \mathrm{~h}\end{array}$ & $\begin{array}{l}\text { Hobo: } 2 \mathrm{~h} \\
\text { iButtons: } 4 \mathrm{~h}\end{array}$ \\
\hline Snow survey & 23 Apr 2013 & 14 Mar 2013 & 20 Mar 2013 \\
\hline Snow density & $305 \mathrm{~kg} \mathrm{~m}^{-3}$ & $340 \mathrm{~kg} \mathrm{~m}^{-3}$ & $338 \mathrm{~kg} \mathrm{~m}^{-3}$ \\
\hline Avg velocity & $238{\mathrm{~m} \mu \mathrm{s}^{-1}}^{-1}$ & $232 \mathrm{~m} \mu \mathrm{s}^{-1}$ & $233 \mathrm{~m} \mu \mathrm{s}^{-1}$ \\
\hline Length of GPR survey & $28 \mathrm{~km}$ & $11 \mathrm{~km}$ & $16 \mathrm{~km}$ \\
\hline Sample points & 23330 & 7957 & 14665 \\
\hline
\end{tabular}

Finse railway station (Fig. 1, bottom). The study area rises around $100 \mathrm{~m}$ above the valley bottom and features a rough and undulating topography. It is located in the high Alpine zone, with sparse vegetation, consisting mainly of mosses and lichens. The bedrock is only partly covered by a thin sediment cover or blocky material. Finse is climatically situated in the transition zone between the maritime western coast and the more continental eastern parts of southern Norway. The general lower limit of permafrost in this area is estimated to be $1550 \mathrm{~m}$ a.s.l. (Etzelmüller et al., 2003). However, 
DC-resistivity soundings at $1450 \mathrm{~m}$ a.s.l. (Etzelmüller et al., 1998) and observations of cold ice $\left(<0^{\circ} \mathrm{C}\right)$ at the glacier front of Midtdalsbreen - an outlet glacier of Hardangerjøkulen (1400 m a.s.l.; Liestøl and Sollid, 1980; Andersen, 1996; Hagen, 1978; Etzelmüller et al., 1998) - indicate permafrost at lower elevations, at least at snow-free sites (Lilleøren et al., 2013). Annual mean air temperature at the field site was $-2.8^{\circ} \mathrm{C}$ for $2012-2013$. The measured precipitation at the official meteorological station (large black circle in Fig. 1, bottom), located $1.5 \mathrm{~km}$ from the field area for the same period, was $708 \mathrm{~mm}$ (eKlima, 2013). More than half of the measured precipitation came as snow, but a severe undercatch of up to $60 \%$ must also be expected at Finse. The snow pack usually starts to build up in October, reaches, on average, $3 \mathrm{~m}$ at snow maximum in the terrain (seNorge.no, 2013) and lasts until June or early July. The prevailing wind direction is from the west, and high gale and storm frequency during winter season results in a pronounced spatial variability of the snow heights in the field area. The mean wind speed during the winter season 2012-2013 was $4.9 \mathrm{~m} \mathrm{~s}^{-1}$, with maximum wind speeds of $28.7 \mathrm{~m} \mathrm{~s}^{-1}$ and mean wind speed during snow precipitation events of $5.5 \mathrm{~m} \mathrm{~s}^{-1}$.

\section{Methods}

\subsection{Ground surface temperature measurements}

A total of 171 temperature data loggers recorded GSTs $(2 \mathrm{~cm}$ below ground surface) with a 2-4 h temporal resolution over 1 hydrological year, including the winter season 2012-2013. The data loggers are mainly iButtons (Maxim Integrated), small loggers $(<2 \mathrm{~cm})$ with included temperature sensors with an accuracy of $\pm 0.5^{\circ} \mathrm{C}$ and a $0.06^{\circ} \mathrm{C}$ resolution. At wet sites, waterproof "HOBO Water Temperature Pro v2" data loggers (Onset Computer Corporation) were used, featuring a $0.02{ }^{\circ} \mathrm{C}$ resolution and a sensor with $\pm 0.2^{\circ} \mathrm{C}$ accuracy. At Juvvasshøe, five UTL-3 (GEOTEST and SLF) loggers (resolution of $<0.1^{\circ} \mathrm{C}$ and accuracy of $0.1^{\circ} \mathrm{C}$ ), partly operational since 1999 (Isaksen et al., 2011), were included in the data set. The loggers were distributed to represent the sub-grid variation of GST within the study areas. In Ny-Ålesund, 104 loggers were randomly distributed over a $0.4 \mathrm{~km}^{2}$ area [85 iButtons, 19 HOBO] (Fig. 1, top, right), with coordinates generated by a random number generator. In all, 26 loggers were installed with $20 \mathrm{~m}$ spacing over a $500 \mathrm{~m}$ long transect pointing down slope at the Juvvasshøe field site [21 iButtons, 5 UTL-1] (Fig. 1, middle, right). At Finse, 24 HOBO loggers were randomly distributed in a $500 \mathrm{~m} \times 500 \mathrm{~m}$ area, while 17 iButton loggers were installed with $20 \mathrm{~m}$ spacing over a $500 \mathrm{~m} \mathrm{E-W}$ transect (Fig. 1, lower, right). All loggers were installed approximately $3 \mathrm{~cm}$ below the ground surface to avoid direct insolation during the snow-free season. The height of snow (HS) for each data logger was measured manually with a probe at maximum snow height. Daily height of snow is measured at one location within each field area, and the observation date matches well with the maximum HS at all three sites.

The measurement periods vary slightly between the three sites (Table 1). The data series from Juvvasshøe lacks 13 days at the end of July to contain a full year of data, so that air temperatures measured at the site were used to fill the data gap (all loggers were free of snow when the gap filling was applied).

\subsection{Snow height surveys}

Snow surveys using ground penetrating radar (GPR) were carried out around the time of maximum snow heights (on the same date as the manual probe measurements at the data loggers were done). Maximum snow height was derived from snow depth sensors at each of the three sites. The GPR data were collected using an impulse radar system (RAMAC, Malå GeoScience) with a shielded antenna at the frequency of $800 \mathrm{MHz}$. A GPS receiver simultaneously recorded the positions together with the GPR. The GPR control unit, the antenna and the GPS were mounted on a sledge and pulled by a snowmobile with a driving speed between 5 and $10 \mathrm{~m} \mathrm{~s}^{-1}$. Radar traces were acquired at intervals of $0.25 \mathrm{~s}$, resulting in spatial intervals of $1.3-2.5 \mathrm{~m}$. The surveys extend for $10-30 \mathrm{~km}$ at each site, and consist of more than 45000 processed data points in total (Table 1). The tracks cover an area of $1 \mathrm{~km} \times 1 \mathrm{~km}$ around the logger sites, and are sampled as a grid in Ny-Ålesund and Finse. At Juvvasshøe, the tracks were made along the terrain gradient instead of a grid, due to the steep topography. Stake measurements taken along the radar tracks served as validation points for the processed radar data, and temperature and density profiles of the snow pack were measured at three sites in the field area at the day of the snow survey.

The processing of the GPR data followed Dunse et al. (2009) and included static correction and frequency filtering, as well as removal of constant time-delay clutter. Since the snow pack was at freezing temperatures during all surveys, the wave speed of the radar signal in dry snow was derived from the permittivity and the speed of light in vacuum, with the permittivity obtained from snow density by an empirical relation (Kovacs et al., 1995). The snow height was determined from the two-way travel time of the reflection from the ground surface and the wave speed.

Errors in the determination of snow heights mainly arise from the lateral variability of the snow density and from the picking accuracy of the radar reflection from the ground surface. The largest variability of snow density was found at Finse, with measured densities of $334 \pm 40 \mathrm{~kg} \mathrm{~m}^{-3}$. This translates to wave speeds of $234 \pm 6 \mathrm{~m} \mathrm{ss}^{-1}$ and an uncertainty of $\pm 2 \mathrm{~cm}$ for a snow height of $1 \mathrm{~m}$. On the other hand, inaccurate picking of the ground surface reflection may introduce errors in the range of $10-15 \mathrm{~cm}$, so that it constitutes the largest source of uncertainty. For shallow snow packs, 
the strong vibrations of the GPR antenna can lead to a noisy signal and, thus, lower accuracy.

The GPR data at Juvvasshøe and Finse most likely underrepresent snow heights below $10 \mathrm{~cm}$, mainly since bareblown areas are underrepresented in the GPR tracks due to driving restriction with the snowmobile. Secondly, some areas with very shallow snow could not be processed at all due to the noisy signal. The underrepresentation of shallow snow cover is strongest at Juvvasshøe, where large entirely bare blown areas could not be covered by the GPR. The gentle topography at the Ny-Ålesund site facilitated slow driving speed over a regular grid, so that the area was very well represented.

\subsection{Model implementation of CryoGRID 1}

The equilibrium permafrost model CryoGRID 1 (Gisnås et al., 2013) provides an estimate for the mean annual ground surface temperature (MAGST) from freezing and thawing degree days in the air $\left(\mathrm{DDF}_{\mathrm{a}}\right.$ and $\left.\mathrm{DDT}_{\mathrm{a}}\right)$, with $n$ factors representing the surface offset caused by the snow cover. MAGST is calculated as

MAGST $=\frac{\left(\mathrm{DDT}_{\mathrm{a}} \times n_{\mathrm{T}}-\mathrm{DDF}_{\mathrm{a}} \times n_{\mathrm{F}}\right)}{P}$,

where $n_{\mathrm{T}}$ and $n_{\mathrm{F}}$ are $n$ factors in the summer and winter season, and $P$ is the number of days in 1 year. To simulate the distribution of ground temperatures within the study areas, CryoGRID 1 is run for the entire range of GPR-measured snow heights for bins of a $0.25 \mathrm{~m}$ width (Fig. 4). The model is forced by degree days measured at the meteorological stations at each site. The $n_{\mathrm{F}}$ factors are parameterized as functions of snow height, where

$n_{\mathrm{F}}=-0.187 \cdot \ln (\mathrm{HS})+0.399$,

and $n_{\mathrm{T}}$ has a constant value of 1 . This relation is based on independent observations of air and ground surface temperatures, as well as snow heights at 15 stations in southern Norway over the period 2009-2012, published in Gisnås et al. (2013).

\section{Results}

\subsection{Observed distribution of ground surface temperatures}

The observed average MAGST of all loggers at Ny-Ålesund, Juvvasshøe and Finse is $-1.6,-0.5$ and $0.8^{\circ} \mathrm{C}$, respectively. However, there is a large spread in MAGST of 5.0, 2.8 and $4.5^{\circ} \mathrm{C}$ at the three sites (Fig. 2), with 98,77 and $30 \%$ of the GST loggers featuring a MAGST below $0{ }^{\circ} \mathrm{C}$.

The largest variability in monthly mean temperatures is found during the winter months with a developed snow cover (January-April). At Finse, the variation is up to $7^{\circ} \mathrm{C}$ in
March (Fig. 3). During the snow-free period (July-October), the observed spatial variability is very low, with most of the loggers being within a $1{ }^{\circ} \mathrm{C}$ variation at each site. Finse features a significantly larger variability than the two other sites during winter, coinciding with a larger variation in snow cover. The median at Finse is close to $0^{\circ} \mathrm{C}$ during the entire winter, showing that GST is decoupled from the air temperature in large parts of the field area and that permafrost is not present in most of the area.

The duration of the snow cover at each logger site was calculated from the difference in diurnal temperature amplitudes at the ground surface and in the air, following Hipp (2012). The duration of snow varies between 100 to 280 days at all three field sites, with an average of 220, 180 and 210 days of snow cover at Ny-Ålesund, Juvvasshøe and Finse. A large variability of GST is observed during the melt out period in June (Fig. 3) due to the pattern of snow-covered and snow-free areas at this time. The low variability during May is related to the ripening phase of the snow pack, with ground surface temperatures close to $0^{\circ} \mathrm{C}$ at many of the measurement sites, and the zero-curtain effect, resulting from the phase change when the ground thaws.

\subsection{Distribution of snow heights}

The distributions of annual maximum snow heights are displayed in Fig. 4. The average snow heights at the GSTlogger sites were $0.67,0.50$ and $0.98 \mathrm{~m}$ at the Ny-Ålesund, Juvvasshøe and Finse, respectively (Fig. 4a-c). The total spread in snow heights at the corresponding sites were 1.9, 2.8 and $4.2 \mathrm{~m}$.

The average snow heights from the GPR snow surveys in the three study areas were $0.53,0.93$ and $1.39 \mathrm{~m}$, with a corresponding total spread of $3.5,5.8$ and $6.0 \mathrm{~m}$ (Fig. $4 \mathrm{~d}-\mathrm{f}$ ). The areal fractions with less than $20 \mathrm{~cm}$ of snow were 9, 28 and $10 \%$ at the three sites, while the fractions with snow heights of less than $1 \mathrm{~m}$ were 92,66 and $49 \%$.

\subsection{Observed distribution of surface offset}

The thawing/freezing degree days in the air that were calculated at each field site were 533/1904 for Ny-Ålesund, $838 / 1943$ for Juvvasshøe and 874/1684 for Finse. The observed values of $n_{\mathrm{F}}$ varied between 0.02 and 1.25 at the three sites, with $43 \%$ (Ny-Ålesund), $67 \%$ (Finse) and $75 \%$ (Juvvasshøe) of the variation in $n_{\mathrm{F}}$, explained by maximum snow height. The effect of the snow as an insulator is also related to the amount of heat released by the active layer during freezing (Riseborough and Smith, 1998; Throop et al., 2012), but this effect has not been included here.The observed values of $n_{\mathrm{T}}$ varied less at the three sites, with mean $n_{\mathrm{T}}$ being 1.2 (Ny-Ålesund), 1.1 (Juvvasshøe) and 1.0 (Finse) with respective standard deviations of $0.11,0.15$ and 0.16 . At a sub-grid level, the variation in $n_{\mathrm{T}}$ can also partly be explained by snow height, in a larger degree at the two most southerly sites than 

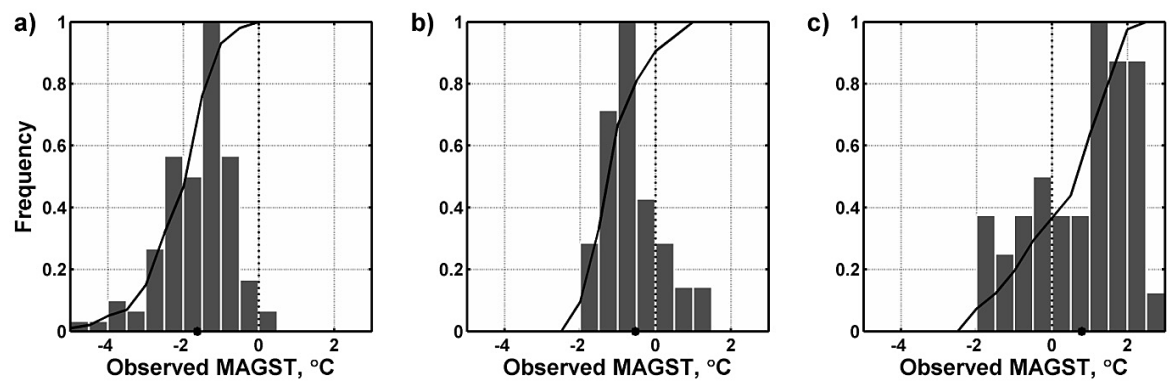

Figure 2. Histograms of measured mean annual ground surface temperatures (MAGSTs) at the logger sites in (a) Ny-Ålesund, (b) Juvvasshøe and (c) Finse. The cumulative curve is given as a solid black line, and average MAGST is marked with a black dot on the $x$ axis. The fraction of samples below $0{ }^{\circ} \mathrm{C}$ is given by the intersection of the cumulative curve and the $0^{\circ} \mathrm{C}$ line (stippled line).

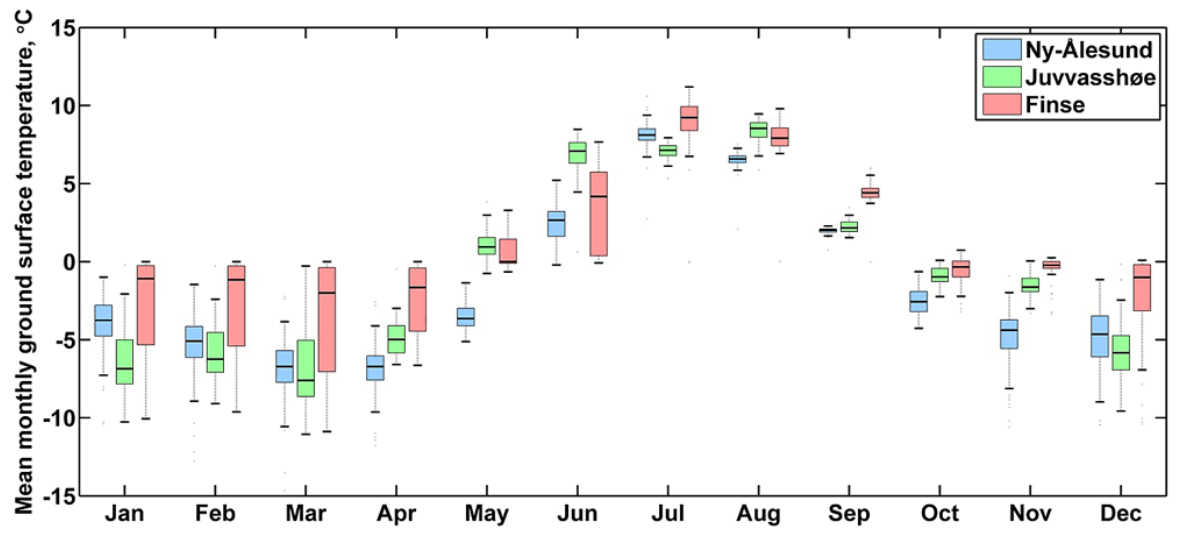

Figure 3. Variation of ground surface temperatures between the loggers at the three field sites. The bars indicate the 25 th and 75 th percentiles, while the whiskers indicate minimum and maximum values. The median is given as a horizontal line in each bar.

at Svalbard. This accounts for the variability in length of the thawing season in the ground due to the variability in timing of melt out. A constant $n_{\mathrm{T}}$ might therefore not be valid at more southerly locations, where DDTs are higher and the timing of melt out varies more. In these cases, a snow dependence for $n_{\mathrm{T}}$ should be included.

\subsection{Modeling small-scale variability of MAGST}

CryoGRID 1 was run for the distribution of snow heights measured with GPR at the field sites (Fig. 4d-f). The distributions of modeled MAGST are displayed in Fig. 5, with total variations of $5.5^{\circ} \mathrm{C}$ (Ny-Ålesund), $3.9^{\circ} \mathrm{C}$ (Juvvasshøe) and $4.5^{\circ} \mathrm{C}$ (Finse). The corresponding average values of modeled MAGST are $-1.4,-0.2$ and $0.5^{\circ} \mathrm{C}$ (Table 2).

The model results (Fig. 5, red bars) are in good agreement with the observed distributions (Fig. 5, black line), with $r^{2}$ between the distributions of observed and modeled MAGST being 0.9 (Ny-Ålesund), 0.6 (Juvvasshøe) and 0.4 (Finse), using $0.5^{\circ} \mathrm{C}$ bin width. The model result for $\mathrm{Ny}$-Ålesund agrees best with the observation, with an average MAGST $0.2^{\circ} \mathrm{C}$ warmer than measured (Table 2). With $5.5^{\circ} \mathrm{C}$ compared to the observed $5^{\circ} \mathrm{C}$, CryoGRID 1 can reproduce the variation of MAGST well, while the fraction of loggers with sub-zero MAGST is $97 \%$ compared to the observed $98 \%$. The obtained distribution is slightly narrower, which can be explained by differences between the snow heights at the logger sites and the GPR-measured snow heights. The constant value of $n_{\mathrm{T}}=1$ could also partly explain why the extreme values of the distributions are not well reproduced. Nevertheless, the representation is satisfactory for Ny-Ålesund with its large number of GST loggers, while the distributions and average snow heights are not reproduced as accurately at Juvvasshøe and Finse (Fig. 5b and c). Here, the average snow heights at the logger sites are almost $0.5 \mathrm{~m}$ lower than in the GPR survey. Consequently, the model forced with snow heights from the GPR survey produces an average MAGST that is $0.3^{\circ} \mathrm{C}$ too high at Juvvasshøe. This demonstrates the importance of a large sample size to measure a true distribution of snow heights and ground temperatures. However, the model succeeds in reproducing the variability of MAGST well at all three sites.

CryoGRID 1 can also deliver an estimate for temperature at the top of permafrost (Gisnås et al., 2013), so that the results of this study can easily be transferred to ground temperatures. Assuming zero offset between ground surface and ground temperatures, this would result in a modeled 

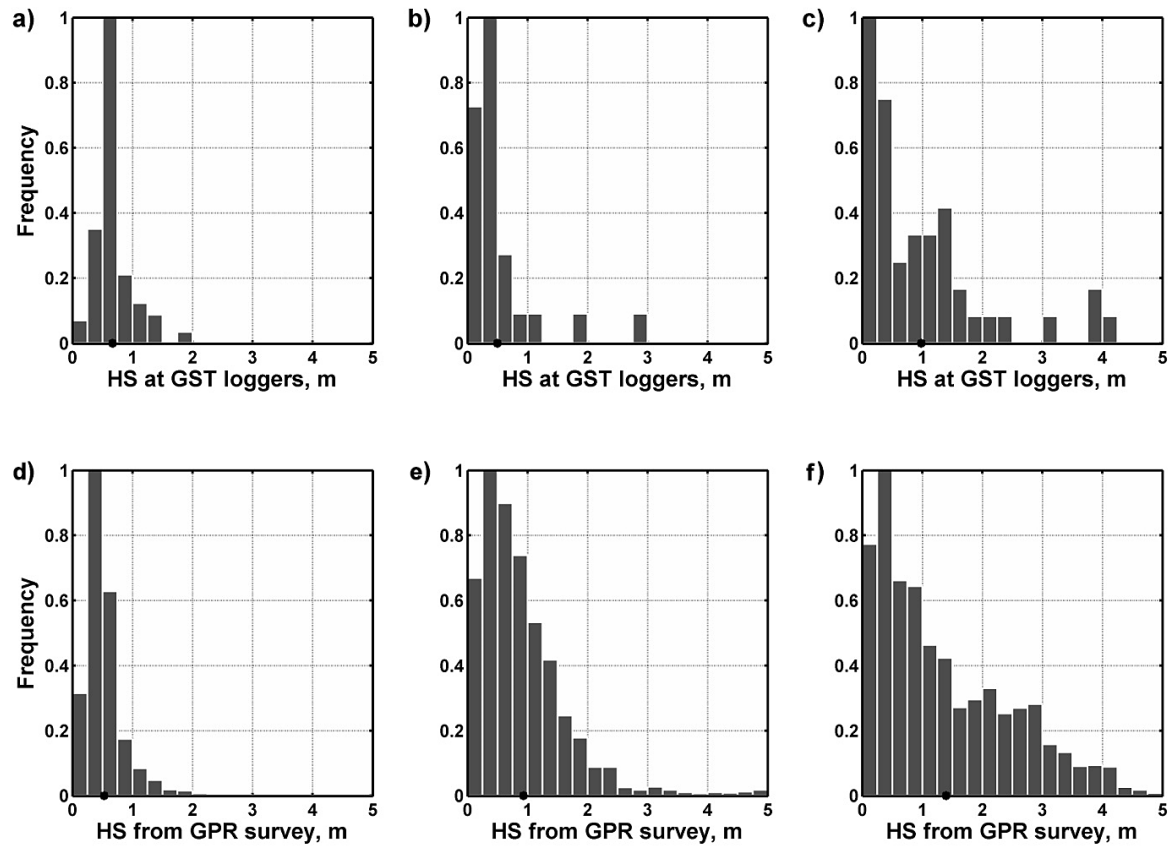

Figure 4. Distributions of the height of snow (HS) at the respective field sites (a) Ny-Ålesund, (b) Juvvasshøe and (c) Finse. Upper row: snow heights measured manually at each logger site; Lower row: snow heights from GPR snow surveys over a $1 \mathrm{~km} \times 1 \mathrm{~km}$ area around the loggers. Black dot: average snow height.

Table 2. Variation in observed mean annual ground surface temperatures (MAGSTs) for 2012-2013 at the study sites, given as mean, minimum, maximum and standard deviation of MAGSTs from all loggers at each site. The percentage of loggers with MAGSTs below $0{ }^{\circ} \mathrm{C}$ is given under " $\%<0{ }^{\circ} \mathrm{C}$ ", and the skewness of the distributions of MAGSTs is given as a number between -1 and 1 .

\begin{tabular}{lrrrrrr}
\hline \multirow{2}{*}{ MAGST } & Mean & Minimum & Maximum & $\begin{array}{c}\text { Standard } \\
\text { deviation }\end{array}$ & $\%<0^{\circ} \mathrm{C}$ & Skewness \\
\hline \multirow{7}{*}{ Observed MAGST } \\
\cline { 2 - 7 } Finse & 0.8 & -1.9 & 2.7 & 1.3 & 30 & -0.59 \\
Juvvasshøe & -0.5 & -1.8 & 1.0 & 0.7 & 77 & 0.58 \\
Ny-Ålesund & -1.6 & -4.6 & 0.5 & 0.9 & 98 & -0.74 \\
& \multicolumn{7}{c}{ Modeled MAGST } \\
Finse & 0.5 & -2.7 & 2.1 & 0.9 & 29 & -0.76 \\
Juvvasshøe & -0.2 & -2.9 & 1.7 & 0.7 & 60 & -0.21 \\
Ny-Ålesund & -1.4 & -4.3 & 0.6 & 0.6 & 97 & -0.41 \\
\hline
\end{tabular}

permafrost fraction of 97,60 and $29 \%$ for the three sites (Fig. 5 and Table 2), as opposed to 98,77 and $30 \%$ in the GST logger surveys. Given the coarse and dry soil conditions at the field sites, in conjunction with the low number of thawing degree days, this is most likely a good approximation of the true conditions. However, this is not necessarily valid for more southerly or continental locations with higher melt rates or numbers of thawing degree days, or locations with high water or organic contents in the ground (e.g., James et al., 2013; Riseborough and Smith, 1998; Smith and Riseborough, 2002; Karunaratne and Burn, 2004).

\section{Discussion}

\subsection{Spatial variability of GST in different permafrost environments}

The investigated field sites show a similar spatial variability in GST, as reported by previous studies (e.g., Etzelmüller et al., 2007; Farbrot et al., 2011; Lewkowicz et al., 2012; Gruber and Hoelzle, 2001). However, other than in most previous studies, the sampling design with a large number of GST loggers facilitated estimating the distribution of GST, so that a statistical modeling approach for the small-scale variability could be validated. A similar study was performed in the 

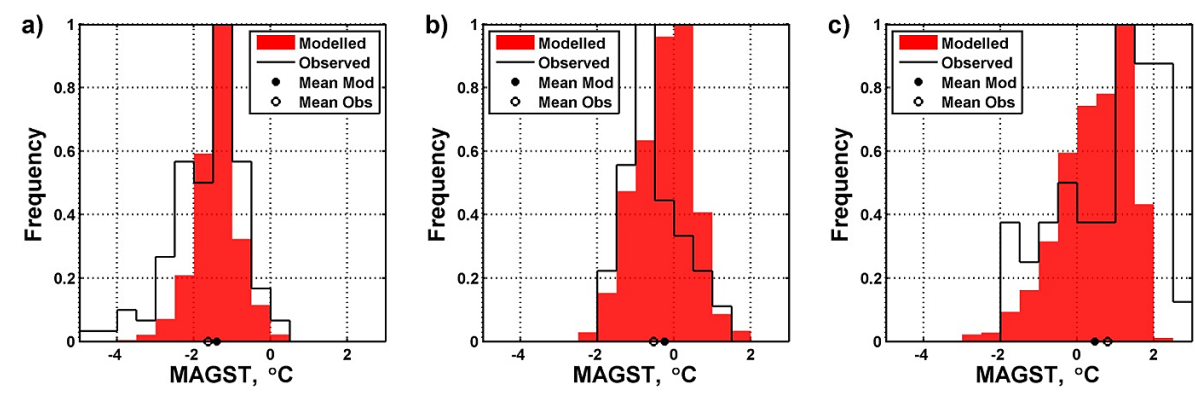

Figure 5. Distribution of modeled (red bars) and observed (black line) MAGST at the (a) Ny-Ålesund, (b) Juvvasshøe and (c) Finse field sites. Average MAGST is marked with a black dot (modeled) and circle (observed) on the $x$ axis.

Swiss Alps by Gubler et al. (2011), who systematically studied variations of GST within footprints of $<100 \mathrm{~m}^{2}$. They found a $6{ }^{\circ} \mathrm{C}$ variation in MAGSTs within an elevation band of $300 \mathrm{~m}$ in the Swiss Alps, and a $2.3^{\circ} \mathrm{C}$ variation within a footprint of $100 \mathrm{~m}^{2}$.

The observed variability at the low-relief high Arctic site in Ny-Ålesund was similar to the alpine environment in southern Norway. Figure 3 demonstrates that most of the variation in GST occurs during the presence of snow cover at all sites, although the range of snow heights in Ny-Ålesund is relatively small compared to Finse. In Ny-Ålesund, most of the observed snow heights are in the range $40-70 \mathrm{~cm}$, with $90 \%$ of the measurements being below $1 \mathrm{~m}$. The insulating effect of the snow cover varies most in this range (Haeberli, 1973; Keller and Gubler, 1993; Luetschg et al., 2008), which is reflected in relatively larger variability in GST when the snow cover varies around a mean value less than $1 \mathrm{~m}$ compared to a mean value above $1 \mathrm{~m}$. At lower latitudes at Juvvasshøe and Finse, the summer season is relatively more important for the ground thermal regime than the winter is. Thus, even with almost double variation of snow heights at Finse compared to Ny-Ålesund, there is less variation in MAGSTs. Furthermore, smaller fractions of the observed snow heights at these two sites are below $1 \mathrm{~m}$ ( 65 and $50 \%$ at Juvvasshøe and Finse). Since GST becomes disconnected from the air temperatures at snow heights above approximately $1 \mathrm{~m}$, the large variation from 1 to $6 \mathrm{~m}$ found at the two southern sites are of minor importance for the GST variation. On the other hand, this will also lead to differences in the timing of the snowmelt and thus the thawing degree days, which is not accounted for by using a constant $n_{\mathrm{T}}$ factor. However, due to the generally low number of thawing degree days at the study sites, the agreement between modeled and measured distributions of ground temperature is still reasonable.

The size of the field areas in this study are chosen to exclude ground temperature variation related to factors varying on larger spatial scales, such as air temperature and precipitation patterns. Based on hundreds of BTS points taken in Jotunheimen - partly at Juvvasshøe -, Isaksen et al. (2002) found that there is a high correlation to elevation at a larger scale (> 500-600 m), while the very small-scale variation below $20-30 \mathrm{~m}$ is mainly explained by the variation in the interaction of a set of climatic, surface and subsurface factors. Between $20-30 \mathrm{~m}$ and $500-600 \mathrm{~m}$, they found that the variation is explained by snow drift and variation in direct radiation. In agreement with previous results (e.g., Farbrot et al., 2011; Isaksen et al., 2002), the study presented in this paper suggests that variation in snow cover is the dominating factor of influencing spatial variability in GST at scales below 500$600 \mathrm{~m}$ in high latitude alpine environments, such as those in the Scandinavian mountain range.

A 10-year data series of eight ground surface temperature loggers distributed over the $500 \mathrm{~m}$ long transect at Juvvasshøe (partly used in this study) shows a small-scale variation in MAGST by $\pm 1.5-2.0^{\circ} \mathrm{C}$ within a distance of 30 $50 \mathrm{~m}$ and more than $3{ }^{\circ} \mathrm{C}$ within a distance of $100 \mathrm{~m}$ (Isaksen et al., 2011). While the total amount of snow varies from year to year, the relative variation in MAGST between the loggers is more or less the same for all years. Snow height measurements taken at the logger sites at maximum snow height show the same pattern of snow depths every year. These findings suggest that an area has a distinct snow distribution pattern, which may facilitate estimating the annual snow distributions using simple snow redistribution models (e.g., Winstral et al., 2002) and larger-scale precipitation fields.

\subsection{Representation of sub-grid variability in permafrost models by including snow distribution functions}

This study demonstrates that a statistical representation of sub-grid variability is feasible, even in simple permafrost models such as CryoGRID 1 (Fig. 5). Regional permafrost models are forced with spatial fields of climate parameters, such as precipitation, air temperature and surface radiation. A main challenge in permafrost modeling is the pronounced small-scale variability of GSTs, which occur at spatial scales several orders of magnitude below the variation of climatic parameters. For the Scandinavian mountains, a spatial resolution of $1 \mathrm{~km}$ can sufficiently account for regional air temperature and precipitation patterns (Gisnås et al., 2013; Westermann et al., 2013; Etzelmüller, 2013). At such a resolution, 
the sub-grid variability in MAGST is mainly explained by snow cover variations induced by wind drift. This study suggests that the sub-grid distribution of ground temperatures can be statistically modeled if a distribution of snow depths is available. Such distributions can be inferred from snow redistribution models - e.g., Alpine 3D (Lehning et al., 2006), SnowModel (Liston and Sturm, 1998) - or by applying the Winstral terrain parameterization (Winstral et al., 2002). Because of computational expenses and input-data requirements, Alpine 3D and SnowModel are suited for local approaches, while the Winstral terrain parameterization is applicable over larger regions. The main uncertainties in using a terrain parameterization to reproduce sub-grid variability of snow heights are the quality of the digital elevation model (DEM) and the wind data. A statistical representation of sub-grid variability is computationally much less demanding than a deterministic representation on a refined grid, so that application for large areas becomes feasible: for a $1 \mathrm{~km}$ grid cell, the model can be run for, e.g., 10 different bins of snow depths instead of increasing the resolution to $10 \mathrm{~m}$, with computation time increasing by a factor of 10 , instead of 10000 . More importantly, distributions of ground temperatures can be directly related to the traditional concept of permafrost zonation in continuous ( $>90 \%$ of an area), discontinuous $(50-90 \%)$, sporadic $(10-50 \%)$ and isolated $(<10 \%)$ permafrost. The transition from continuous to sporadic permafrost in a warming climate can thus be inherently described by such a sub-grid concept, while area-averaged formulations for large grid cells can only deliver a single ground temperature for each grid cell. Permafrost degradation can occur in a small part of a grid cell, although the permafrost model (or the closest borehole) suggests stable permafrost. Even if degradation occurs only over a small fraction of the area, it can trigger nonlinear processes, such as thermokarst or thaw slumps, affecting the larger-scale surface fluxes of energy, water and carbon. This is also important for determining local scale impacts on drainage and ecosystems resulting from changing permafrost conditions, as well as for lowering the costs related to infrastructure planning and design. The occurrence of positive MAGST in Ny-Ålesund for a small fraction of the GST loggers (Fig. 2) suggests the onset of degradation at localized sites, which would be obscured when only considering area averages of MAGST. For simulating the effects of climate change on ground temperatures, employing an empirical equilibrium approach, such as the temperature of the top of permafrost (TTOP) model (Smith and Riseborough, 1996), is highly questionable, since the transient response of the ground to changing temperature forcing is not captured. Furthermore, parameters assumed constant in the modeling, in particular the $n$ factors, may change in the future. However, at least for data-sparse regions, the performance of simple empirical approaches may not necessarily be worse than that of more sophisticated approaches, for which a number of generally unknown model parameters must be constrained.
The statistical representation of sub-grid variability can be extended to include other factors; e.g., exposition, land cover or ground thermal properties. However, this would require multi-dimensional distribution functions, which can describe the potentially complex correlations between statistically dependent parameters (e.g., between snow depths and surface soil moisture). It is thus important that such modeling efforts are strongly guided by field studies on the governing parameters for the ground thermal regime in a particular region. In the study areas, the variability of ground temperatures can, to a large degree, be described by the variability of snow depths, which, in turn, depends on wind exposure. However, this is not necessarily true for other permafrost areas - for instance, for more southerly permafrost areas, where exposition can be a strong additional control due to larger values of incoming radiation (Gruber et al., 2004; Gubler et al., 2011).

\section{Conclusions}

At three sites along a transect from Svalbard to southern Norway, the distributions of ground surface temperatures are recorded within areas of $0.5 \mathrm{~km}^{2}$ by 171 temperature loggers in total. With the data set, a statistical approach to include the small-scale variability of temperatures in a simple permafrost model could be validated.

From this study, the following conclusions can be drawn:

- In high-mountain and arctic areas dominated by strong winds, wind drift of snow creates a pattern of snow depths, resulting in a pronounced small-scale variability of mean annual ground surface temperatures.

- The small-scale variability of ground surface temperatures is most pronounced during the winter months with a developed snow cover and during snowmelt, while the variability is comparatively small during summer and early winter.

- If the spatial distribution of snow heights is known, a statistical representation of the spatial variability of ground surface temperatures is feasible, even in a simple permafrost model.

The study exemplifies the necessity of representing the subgrid variability of ground temperatures in larger-scale model approaches. A statistical representation of snow cover and ground temperatures within model grid cells can facilitate application over large areas. 
Acknowledgements. The research in $\mathrm{Ny}$-Ålesund was funded by the Arctic Field Grant (Norwegian Research Council) and CryoMet (project no. 214465; funded by the Norwegian Research Council). The project at Juvvasshøe was done in collaboration with Rune Strand Ødegård in Klimapark 2469. The project at Finse was partly founded by the hydropower companies Statkraft and ECO. In addition, the following colleagues from the University of Oslo helped out in the field: Trond Eiken, Kristin Sæterdal Myhra, Kjetil Aas, Torborg Heid, Ladina Steiner, Désireé Treichler, Maria Peter and Bas Altena. We gratefully acknowledge the support of all mentioned individuals and institutions.

Edited by: T. Zhang

\section{References}

Andersen, L. M.: En brehydrologisk unders $\emptyset$ kelse av Midtdalsbren, Sør-Norge, Cand. Scient. thesis, Department of Geosciences, University of Oslo, Oslo, 74 pp., 1996.

Boike, J., Roth, K., and Ippisch, O.: Seasonal snow cover on frozen ground: Energy balance calculations of a permafrost site near Ny-Ålesund, Spitsbergen, J. Geophys. Res., 108, 8163, doi:10.1029/2001JD000939, 2003.

Boike, J., Ippisch, O., Overduin, P. P., Hagedorn, B., and Roth, K.: Water, heat and solute dynamics of a mud boil, Spitsbergen, Geomorphology, 95, 61-73, doi:10.1016/j.geomorph.2006.07.033, 2008.

Bruland, O., Sand, K., and Killingtveit, A.: Snow distribution at a high arctic site at Svalbard, Nord. Hydrol., 32, 1-12, 2001.

Dunse, T., Schuler, T. V., Hagen, J. O., Eiken, T., Brandt, O., and Høgda, K. A.: Recent fluctuations in the extent of the firn area of Austfonna, Svalbard, inferred from GPR, Ann. Glaciol., 50, 155-162, doi:10.3189/172756409787769780, 2009.

eKlima: Free access to weather and climate data from the Norwegian Meteorological Institute: www.eklima.no, 2013.

Etzelmüller, B.: Recent advances in mountain permafrost research, Permafrost Periglac., 24, 99-107, doi:10.1002/ppp.1772, 2013.

Etzelmüller, B., Berthling, I., and Sollid, J. L.: The distribution of permafrost in Southern Norway; a GIS approach, Seventh International Conference on Permafrost, Proceedings, Université Lavall, Québec, PQ, Canada, 251-257, 1998.

Etzelmüller, B., Berthling, I., and Sollid, J. L.: Aspects and concepts on the geomorphological significance of Holocene permafrost in southern Norway, Geomorphology, 52, 87-104, doi:10.1016/s0169-555x(02)00250-7, 2003.

Etzelmüller, B., Farbrot, H., Guðmundsson, Á., Humlum, O., Tveito, O. E., and Björnsson, H.: The regional distribution of mountain permafrost in Iceland, Permafrost Periglac., 18, 185199, doi:10.1002/ppp.583, 2007.

Farbrot, H., Hipp, T. F., Etzelmüller, B., Isaksen, K., Ødegård, R. S., Schuler, T. V., and Humlum, O.: Air and ground temperature variations observed along elevation and continentality gradients in Southern Norway, Permafrost Periglac., 22, 343-360, doi:10.1002/ppp.733, 2011.

Førland, E. and Hanssen-Bauer, I.: Increased precipitation in the Norwegian Arctic: true or false?, Climatic Change, 46, 485-509, doi:10.1023/A:1005613304674, 2000.

Gisnås, K., Etzelmuller, B., Farbrot, H., Schuler, T. V., and Westermann, S.: CryoGRID 1.0: permafrost distribution in Norway es- timated by a spatial numerical Model, Permafrost Periglac., 24, 2-19, doi:10.1002/ppp.1765, 2013.

Goodrich, L. E.: The influence of snow cover on the ground thermal regime, Can. Geotech. J., 19, 421-432, 1982.

Gruber, S. and Hoelzle, M.: Statistical modelling of mountain permafrost distribution: local calibration and incorporation of remotely sensed data, Permafrost Periglac., 12, 69-77, doi:10.1002/ppp.374, 2001.

Gruber, S., King, L., Kohl, T., Herz, T., Haeberli, W., and Hoelzle, M.: Interpretation of geothermal profiles perturbed by topography: the alpine permafrost boreholes at Stockhorn Plateau, Switzerland, Permafrost Periglac., 15, 349-357, doi:10.1002/ppp.503, 2004.

Gubler, S., Fiddes, J., Keller, M., and Gruber, S.: Scaledependent measurement and analysis of ground surface temperature variability in alpine terrain, The Cryosphere, 5, 431-443, doi:10.5194/tc-5-431-2011, 2011.

Haeberli, W.: Die Basis-Temperatur der winterlichen Schneedecke als möglicher Indikator für die Verbreitung von Permafrost in den Alpen, Zeitschrift für Gletscherkunde und Glazialgeologie, 9, 221-227, 1973.

Hagen, J. O.: Brefrontprosesser ved Hardangerjøkulen (Midtdalsbreen, Blåisen og Brattfonn), Cand. Scient., Geography Department, University of Oslo, Oslo, 105 pp., 1978.

Harris, C., Arenson, L. U., Christiansen, H. H., Etzelmüller, B., Frauenfelder, R., Gruber, S., Haeberli, W., Hauck, C., Hölzle, M., Humlum, O., Isaksen, K., Kääb, A., Lehning, M., Lütschg, M. A., Matsuoka, N., Murton, J., Nötzli, J., Phillips, M., Ross, N., Seppälä, M., Springman, S., and Vonder Muhll, D.: Permafrost and climate in Europe: monitoring and modelling thermal, geomorphological and geotechnical responses, Earth-Sci. Rev., 92, 117-171, 2009.

Hauck, C., Isaksen, K., Mühll, D. V., and Sollid, J. L.: Geophysical surveys designed to delineate the altitudinal limit of mountain permafrost: an example from Jotunheimen, Norway, Permafrost Periglac., 15, 191-205, doi:10.1002/ppp.493, 2004.

Hipp, T., Etzelmüller, B., Farbrot, H., Schuler, T. V., and Westermann, S.: Modelling borehole temperatures in Southern Norway - insights into permafrost dynamics during the 20th and 21 st century, The Cryosphere, 6, 553-571, doi:10.5194/tc-6-553-2012, 2012.

Isaksen, K., Holmlund, P., Sollid, J., and Harris, C.: Three deep alpine-permafrost boreholes in Svalbard and Scandinavia, Permafrost Periglac., 12, 13-25, doi:10.1002/ppp.380, 2001.

Isaksen, K., Hauck, C., Gudevang, E., Ødegård, R. S., and Sollid, J. L.: Mountain permafrost distribution in Dovrefjell and Jotunheimen, southern Norway, based on BTS and DC resistivity tomography data, Norsk Geogr. Tidsskr., 56, 122-136, doi:10.1080/002919502760056459, 2002.

Isaksen, K., Heggem, E., Bakkehøi, S., Ødegård, R., Eiken, T., Etzelmüller, B., and Sollid, J.: Mountain permafrost and energy balance on Juvvasshøe, southern Norway, Eight International Conference on Permafrost, Zurich, Switzerland, 467-472, 2003.

Isaksen, K., Sollid, J. L., Holmlund, P., and Harris, C.: Recent warming of mountain permafrost in Svalbard and Scandinavia, J. Geophys. Res., 112, F02S04, doi:10.1029/2006jf000522, 2007.

Isaksen, K., Ødegård, R. S., Etzelmüller, B., Hilbich, C., Hauck, C., Farbrot, H., Eiken, T., Hygen, H. O., and Hipp, T. F.: Degrading mountain permafrost in Southern Norway: spatial and temporal 
variability of mean ground temperatures, 1999-2009, Permafrost Periglac., 22, 361-377, doi:10.1002/ppp.728, 2011.

Ishikawa, M.: Thermal regimes at the snow-ground interface and their implications for permafrost investigation, Geomorphology, 52, 105-120, doi:10.1016/S0169-555X(02)00251-9, 2003.

James, M., Lewkowicz, A. G., Smith, S. L., and Miceli, C. M.: Multi-decadal degradation and persistence of permafrost in the Alaska Highway corridor, northwest Canada, Environ. Res. Lett., 8, 045013, doi:10.1088/1748-9326/8/4/045013, 2013.

Karunaratne, K. and Burn, C.: Relations between air and surface temperature in discontinuous permafrost terrain near Mayo, Yukon Territory, Canadian J. Earth Sci., 41, 1437-1451, 2004.

Keller, M. and Gubler, H.: Interaction between snow cover and high-mountain permafrost, Murtel/Corvatsch, Swiss Alps, in: Proceedings after Sixth International Conference on Permafrost, Beijing, China, 332-337, 1993.

Kovacs, A., Gow, A. J., and Morey, R. M.: The in-situ dielectric constant of polar firn revisited, Cold Reg. Sci. Technol., 23, 245256, doi:10.1016/0165-232X(94)00016-Q, 1995.

Langer, M., Westermann, S., Heikenfeld, M., Dorn, W., and Boike, J.: Satellite-based modeling of permafrost temperatures in a tundra lowland landscape, Remote Sens. Environ., 135, 12 24, doi:10.1016/j.rse.2013.03.011, 2013.

Lehning, M., Völksch, I., Gustafsson, D., Nguyen, T. A., Stähli, M., and Zappa, M.: ALPINE3D: a detailed model of mountain surface processes and its application to snow hydrology, Hydrol. Process., 20, 2111-2128, doi:10.1002/hyp.6204, 2006.

Lewkowicz, A. G., Bonnaventure, P. P., Smith, S. L., and Kuntz, Z.: Spatial and thermal characteristics of mountain permafrost, northwest Canada, Geogr. Ann. A, 94, 195-213, doi:10.1111/j.1468-0459.2012.00462.x, 2012.

Liestøl, O. and Sollid, J. L.: Glacier erosion and sedimentation at Hardangerjøkulen and Omsbreen, in: Field Guide to Excursion Organized in Conjunction with Symposium on Processes of Glacer Erosion and Sedimentation, 25-30 August, edited by: Orheim, O., Norwegian Polar Institute, Geilo, 1980.

Lilleøren, K. S., Humlum, O., Nesje, A., and Etzelmüller, B.: Holocene development and geomorphic processes at Omnsbreen, southern Norway: evidence for glacier-permafrost interactions, Holocene, 23, 796-809, doi:10.1177/0959683612471984, 2013.

Liston, G. E. and Sturm, M.: A snow-transport model for complex terrain, J. Glaciol., 44, 498-516, 1998.

Luetschg, M., Stoeckli, V., Lehning, M., Haeberli, W., and Ammann, W.: Temperatures in two boreholes at Flüela Pass, Eastern Swiss Alps: the effect of snow redistribution on permafrost distribution patterns in high mountain areas, Permafrost Periglac., 15, 283-297, doi:10.1002/ppp.500, 2004.

Luetschg, M., Lehning, M., and Haeberli, W.: A sensitivity study of factors influencing warm/thin permafrost in the Swiss Alps, J. Glaciol., 54, 696-704, doi:10.3189/002214308786570881, 2008.

Mohr, M.: New Routines for Gridding of Temperature and Precipitation Observations for "seNorge.no". Met.no Report 08/2008, available at: http://met.no/Forskning/Publikasjoner/ Publikasjoner_1995_-_2012/Publikasjoner_2008/filestore/ NewRoutinesforGriddingofTemperature.pdf, last access: January 2013), 2008.

Ødegård, R. S., Sollid, J. L., and Liestøl, O.: Ground temperature measurements in mountain permafrost, Jotun- heimen, southern Norway, Permafrost Periglac., 3, 231-234, doi:10.1002/ppp.3430030310, 1992.

Riseborough, D. and Smith, M.: Exploring the limits of permafrost., Seventh International Conference on Permafrost, Yellowknife, Canada, 935-941, 1998

Roth, K. and Boike, J.: Quantifying the thermal dynamics of a permafrost site near Ny-Ålesund, Svalbard, Water Resour. Res., 37, 2901-2914, doi:10.1029/2000WR000163, 2001.

Saloranta, T. M.: Simulating snow maps for Norway: description and statistical evaluation of the seNorge snow model, The Cryosphere, 6, 1323-1337, doi:10.5194/tc-6-1323-2012, 2012.

seNorge.no: Gridded data sets of air temperature and snow depth for Norway, available at: www.seNorge.no (last access: 4 November 2013), 2013

Smith, M. W. and Riseborough, D. W.: Permafrost monitoring and detection of climate change, Permafrost Periglac., 7, 301-309, doi:10.1002/(SICI)1099-1530(199610)7:4<301::AIDPPP231>3.0.CO;2-R, 1996.

Smith, M. W. and Riseborough, D. W.: Climate and the limits of permafrost: a zonal analysis, Permafrost Periglac., 13, 1-15, doi:10.1002/ppp.410, 2002.

Sollid, J. L., Holmlund, P., Isaksen, K., and Harris, C.: Deep permafrost boreholes in western Svalbard, northern Sweden and southern Norway, Norsk Geogr. Tidsskr., 54, 186-191, doi:10.1080/002919500448567, 2000.

Throop, J., Lewkowicz, A. G., and Smith, S. L.: Climate and ground temperature relations at sites across the continuous and discontinuous permafrost zones, northern Canada, Can. J. Earth Sc., 49, 865-876, doi:10.1139/e11-075, 2012.

Tveito, O. E., Førland, E. J., Heino, R., Hanssen-Bauer, I., Alexandersson, H., Dahlström, B., Drebs, A., Kern-Hansen, C., Jónsson, T., Laursen, E. V., and Westman, Y.: Nordic temperature maps (Nordklim), DNMI KLIMA Report 09/00, 2000.

Vonder Muhll, D., Stucki, T., and Haeberli, W.: Borehole temperatures in Alpine permafrost: a ten years series, in: Proceedings of the Seventh International Conference on Permafrost, Yellowknife, Canada, 1089-1095, 1998.

Westermann, S., Lüers, J., Langer, M., Piel, K., and Boike, J.: The annual surface energy budget of a high-arctic permafrost site on Svalbard, Norway, The Cryosphere, 3, 245-263, doi:10.5194/tc3-245-2009, 2009

Westermann, S., Wollschläger, U., and Boike, J.: Monitoring of active layer dynamics at a permafrost site on Svalbard using multichannel ground-penetrating radar, The Cryosphere, 4, 475-487, doi:10.5194/tc-4-475-2010, 2010

Westermann, S., Boike, J., Langer, M., Schuler, T. V., and Etzelmüller, B.: Modeling the impact of wintertime rain events on the thermal regime of permafrost, The Cryosphere, 5, 945-959, doi:10.5194/tc-5-945-2011, 2011

Westermann, S., Schuler, T. V., Gisnås, K., and Etzelmüller, B.: Transient thermal modeling of permafrost conditions in Southern Norway, The Cryosphere, 7, 719-739, doi:10.5194/tc-7-7192013, 2013.

Winstral, A., Elder, K., and Davis, R. E.: Spatial snow modeling of wind-redistributed snow using terrain-based parameters, J. Hydrometeorol., 3, 524-538, 2002.

Winther, J.-G., Godtliebsen, F., Gerland, S., and Isachsen, P. E.: Surface albedo in Ny-Ålesund, Svalbard: variability and trends 
during 1981-1997, Global Planet. Change, 32, 127-139, doi:10.1016/S0921-8181(01)00103-5, 2002.

Zhang, T.: Influence of the seasonal snow cover on the ground thermal regime: an overview, Rev. Geophys., 43, 1944-9208, doi:10.1029/2004rg000157, 2005.
Zhang, T., Barry, R. G., and Haeberli, W.: Numerical simulations of the influence of the seasonal snow cover on the occurrence of permafrost at high latitudes, Norsk Geografisk Tidsskrift - Norwegian J. Geography, 55, 261-266, doi:10.1080/00291950152746621, 2001. 